\title{
IGF-1 Gene Polymorphism and Weight-Related Analysis
}

\author{
Wei Li \\ College of Animal Science and Technology of Shihezi University \\ Shihezi, 832003, China \\ E-mail:1wi-xyz@126.com \\ Fangqun Li \\ College of pharmacy of Shihezi University \\ Shihezi, 832003, China \\ E-mail:1fq003@126.com \\ Daquan Li \\ College of Animal Science and Technology of Shihezi University \\ Shihezi, 832003, China \\ E-mail: lidaquan37@163.com
}

\begin{abstract}
The PCR-RFLP technology, Rose crown chicken broiler red cards, the new Roman layer, hybrid chicken (reciprocal cross) of the 50 insulin-like growth factor-I I (IGF-I) gene regulation and control of the 5-end Genetic Polymorphisms of areas, the control region of the PCR products digested by PstI after "-/-" "+/-" "+/+" 3 genotypes, experimental through hybridization chicken (orthogonal and Anti-settlement), Rose chicken crown, the new pro-Roman red cards in this and the pro-IGF-1 to the Pst1-RFLP. Genotype frequency, there "+/+">"+/-">"-/-" trend, but in 12 weeks, body weight, the whole "-/-">"+/-">"+/ + "trend. Which rose crown hybrid chicken and chicken "-/-" >"+/+", orthogonal portfolio significantly different $(\mathrm{P}<0.05)$.
\end{abstract}

Keywords: Chicken, Insulin-Like Growth Factor-I, Weight, PCR-RFLP

\section{Introduction}

Rose giant crown Chickens in China's age-old chicken breeds, the red mulberry-like crown shaped like Xinjiang's Tianshan snow lotus, the colorful, rough-resistant and have fed, cold-resistant and heat resistant and strong, and other biological characteristics of the fine. The existing 2,000 rose only crown chicken meat with delicious, aroma, delicate and delicious, such as quality, this is our country and the world's poultry valuable germplasm resources and breeding material (Liao he rong, 2004, p. 176).

In this experiment, in order to crown the Rose chicken, red cards broilers, layers of the new Roman, red cards and the new hybrid of the Roman chicken (after referred to as the hybrid chicken) for the study to IGF-1 gene as a candidate gene using PCR-RFLP method, The detection of chicken IGF-1 gene polymorphism Pst1, aimed at IGF-1 gene Pst1 restriction site polymorphism in the chicken and weight-related analysis, for further study IGF-1 gene polymorphism and growth The speed of molecular genetic markers to establish a foundation.

\section{Materials and Methods}

\subsection{Experimental Materials}

\subsubsection{Experimental populations}

Rose chicken Canopy test chickens, chickens red cards, the new Roman laying hens, chickens hybrid (cross-positive and negative) of 50, keeping a unified stand in the trial, immunization procedures and keeping management in 
accordance with the general management, as far as possible to ensure that subjects chicken Keeping the same management conditions. 0-3 wk age, 4-8 wk age and 8-12 wk age feeding stage.

\subsubsection{Primer}

Primers used in reference to the Nagaraia $(2000$, p.150) provided by the sequence, the following sequence:

Forward 5'-GACTATACAGAAAGAACCCAC-3', Reverse 5'-TATCACTCAAGTGGCTCAAGT-3'. Primed by the Shanghai Biological Engineering Co., Ltd. synthesis.

\subsection{DNA polymorphism analysis}

\subsubsection{Genomic DNA extraction}

Wing vein blood $0.3 \mathrm{~mL}$ Add $1 \times$ STE $470 \mu 1,10 \%$ SDS $25 \mu$, adding to the concentration of $0.1 \mathrm{mg} / \mathrm{ml}$ of Proteinase $\mathrm{k}$ $5.25 \mu \mathrm{l}, 55{ }^{\circ} \mathrm{C}$ water bath for the night, to fully digest protein and RNA; such as adding the volume of saturated phenol (about 550 $\mathrm{l}$ ), Gently shaken $10 \mathrm{~min}$, centrifugal (12000 rmp) 15min, to draw the DNA-containing supernatant; adding $500 \mu \mathrm{l}$ phenol, chloroform, isoamyl alcohol (25:24:1) mixture, Gently shaken 10min, centrifugal (12000rmp) $15 \mathrm{~min}$, Learned of the DNA-containing supernatant, with chloroform, isoamyl alcohol (24:1) and then extract 1, adding $1 / 10$ the size of $\mathrm{NH}_{4} \mathrm{AC}$ (about $60 \mu \mathrm{l}$ ), blending, add twice the size of the pre-cooling Ethanol, gently mixing, flocculation sediment can be seen, $4{ }^{\circ} \mathrm{C}$ precipitation 1 hour, centrifugal (10000rmp) 10min, to abandon after the supernatant. Precipitation will be placed $20-30 \mathrm{~min}$, to make ethanol volatile clean, and then adding $100 \mu 1 \mathrm{TE}_{4}{ }^{\circ} \mathrm{C}$ refrigerator to preserve back-up.

\subsubsection{Genomic DNA concentration and quality of Determination}

Take DNA solution $10 \mu \mathrm{l}$, adding two-Steam $2.999 \mathrm{ml}$ of the water, fully dissolved by ultraviolet spectrophotometer determination of $260 \mathrm{~nm}$ and $280 \mathrm{~nm}$ wavelength ultraviolet light absorption value of the Department, the nucleic acid absorption in the UV wavelength $260 \mathrm{~nm}$, The protein in the UV absorption peak $280 \mathrm{mn}$, if a more complete removal of protein, samples The $\mathrm{OD}_{260} \mathrm{~nm} / \mathrm{OD}_{280} \mathrm{~nm}$ should be between 1.6-1.8. DNA concentration formula: DNA solution concentration

$=\mathrm{OD}_{260} \mathrm{~nm} \times$ multiple of diluted $\times 50(\mathrm{ng} / \mu \mathrm{l})$. According to the determination of the post-genomic DNA sample concentration, the genomic DNA into a diluted $200 \mathrm{ng} / \mu \mathrm{l}, 4{ }^{\circ} \mathrm{C}$ refrigerator to preserve back-up.

\subsubsection{PCR amplification and PCR-RFLP}

In order to get the best PCR amplification effect on the PCR reaction conditions are optimized, according to the main PCR Factors that affect the order of importance, in order to optimize the annealing temperature, concentration of magnesium and primer concentration(Hertzel AV,2002,p.2106

), and optimize the results are as follows: $25 \mathrm{ul}$ reaction system, 10xBufer $2.5 \mu \mathrm{l}, \mathrm{MgCl} 2(25 \mathrm{mmol} / \mathrm{L}) 1 \mu \mathrm{l}$, dNTPs $(2.5 \mathrm{mmol} / \mathrm{L}) 1.5 \mu \mathrm{l}$, before and after the primer $(5 \mathrm{pmol} / \mathrm{L})$ of all $1 \mu \mathrm{l}$, TaqDNA polymerase $(2.5 \mathrm{U} / \mu \mathrm{l}) 0.5 \mu \mathrm{l}$, template DNA1 $\mu 1$, deionized water $16.5 \mu \mathrm{l}$. PCR conditions were $94^{\circ} \mathrm{C}$ for $5 \mathrm{~min}, 34$ cycles at $94^{\circ} \mathrm{C}$ for $60 \mathrm{~s}, 56^{\circ} \mathrm{C}$ for $120 \mathrm{~s}, 72^{\circ} \mathrm{C}$ for $90 \mathrm{~s}$, and an extension at $72{ }^{\circ} \mathrm{C}$ for $8 \mathrm{~min}, 4^{\circ} \mathrm{C}$ preservation. PCR amplification products by $1 \%$ agarose gel electrophoresis, PCR products by adding $7 \mu$, at the same time adding a total of DNAMarker Beach, for an estimated molecular weight, ethidium bromide staining after the detection results of the expansion. Miscellaneous not with the kind of in order to carry out the next steps.

PCR product of taking $12 \mu$ l, PstI enzyme (10U/ $\mu 1) 1.5 \mu 1$, 10xBuffer $1.5 \mu 1$, plus double-distilled water to $20 \mu 1,37^{\circ} \mathrm{C}$ overnight digestion, the product of the enzyme by $2 \%$ agarose gel electrophoresis, EB stained gel Photo imaging analysis system for detecting genotyping.

\subsection{Statistical analysis}

All data are used spss11.0 statistical analysis software, the distribution of genotypes with $\mathrm{x}^{2}$ test.

\section{Results}

\subsection{PCR-RFLP analysis}

According to the chicken IGF-I gene sequence leading projection, the target for the amplified fragment length $621 \mathrm{bp}$. This study was amplified by the fragment length by $0.8 \%$ agarose gel electrophoresis detection in line with, and not with miscellaneous can be further enzyme digestion (Figure 1).

\subsection{Gene frequency and genotypic frequency}

Product of the enzyme by $2 \%$ agarose gel electrophoresis, EB staining, see the pictures (Figure 2). Map can be seen from a point mutation PstI digestion, that is, a pair of alleles, can not be digested are marked PstI "-" (621 bp), who tags can be digested marked PstI "+" (364bp $+257 \mathrm{bp})$; Combination of the three bands, that is, the three genotypes $("+/+"$ "-/-" "+/-"). S. C. Nagaraia (2000,p.154) this report the results. 
pair of Rose chicken Canopy (to the table in place of MM), red cards broiler (to the table in place of AA), the new Roman layer (the table in order to replace the XX), the chicken cross the orthogonal (to the table in place of AX), Anti-pay (in the table in order to replace the XA) Pstl digested by the combination of genotypes and their frequency and the weight difference in table 2.1 .

Based on the above test, in Table 3.1 are listed in a different IGF-1 chicken Genotype and the relationship between body weight, can be seen from the table, the effect of different varieties of genotypic to show inconsistencies in the law: IGF-1 by enzyme Pst1 The emergence of the three genotypes in the hybrid chicken, Rose chicken Canopy, the new Roman parents and red cards parents on the birth weight is no significant difference. In the anti-settlement,"-/-">"+/+">"+/-"; portfolio in the combination of orthogonal and red cards in this pro-,"+/-">"-/-">"+/ + "; In the Rose and Crown and the new chicken in this pro-Roman,"-/-">"+/-">"+/+"; In the 6-week-old body weight, the chicken cross the new Roman parents, parental red cards and Rose chicken Canopy are the trends "-/-">"+/-">"+/+". But also in the chicken cross the orthogonal combination of Rose and Crown in chicken,"-/-" significantly higher than "+/+" $(\mathrm{P}<0.05)$. In the 9-week-old body, this new pro-Roman and red cards parents still "-/-">"+/->"+/+" a continuation of the trend; 12 weeks after the chicken cross the combination of orthogonal, " -/-">"+/-">"+/+", And "-/-" "+/-" and + / + significant difference $(\mathrm{P}<0.05)$; the chicken cross the anti-cross combination, "+/-">"-/-">"+/+", Three no significant difference ( $\mathrm{P}>0.05)$; in the Rose chicken Canopy in,"-/-">"+/-">"+/+","-/-" And + / + significant difference $(\mathrm{P}<0.05)$.

In Table 2.2, an analysis of the chicken cross (orthogonal and anti-cross), Rose chicken Canopy, the new Roman parents and parents of red cards, rooster and hen of the IGF-1 enzyme Pst1 by the three genotypes And the frequency of gender differences in body weight between. One rooster and hen, after digestion of the three genotypes in "-/-" have shown that the growth speed advantage.

\section{Discussion}

From the above we can see the results: The genotype frequencies, "+/+">"+/-">"-/-" trend, but in the 12-week weight, there is a whole "-/-">" +/-">"+/+". Rose and Crown in which the chicken cross the chicken orthogonal portfolio "-/-" >"+/+", significant difference $(\mathrm{P}<0.05)$. On the IGF-1 gene PstI restriction sites of the relationship between genotype and weight analysis has been done, WANG Zhi-yue (2004,p.11) reported: New Yangzhou chicken "-/-" type than $+/+7.8 \%$ high. Gender differences between the cumulative growth significant genotype effect sex investigation and the findings of a similar merger. Ouyang Jianhua (2003,p.528) reported: in Nanjing are Sanhuang,"-/-" genotype in the 3-month-old chicken weight trends higher than that of other genotypes, which are similar to the experimental results, but he also reported in million Leisure contained in the yellow loci showed heterozygosity advantage. Seo (2001,p.920)has studied the report: local chickens in South Korea KNOC cock,"+/+" genotypes in body weight in 30-week-old chickens were significantly higher than "-/-" type, in the 20-60 week period, greater than the trend of other genotypes.

The results are inconsistent, on the one hand may be due to sampling method and determination of the object due to a difference, such as chicken KNOC is measured body weight after 20 weeks of age, while the yellow Leisure Wanzai only hens were studied; on the other hand, probably because the number of trait loci sit (QTL) expression to a large extent by environmental conditions and genetic background influence on the possibility of using a gene markers as well as any how to make use of feeding and management should be as specific conditions and characteristics of the species.

By this test hybrid chicken (orthogonal and anti-cross), Rose chicken Canopy, the new Roman parents and red cards in this pro-IGF-1 for the Pst1-RFLP. Experimental chickens, including laying hens, chickens, local chickens are hybrid chickens, a more comprehensive comparison of the IGF-1 enzyme Pst1 by the genotype associated with body weight. The results show that the genotype "-/-" as a positive correlation with the weight of good sites for future breeding chickens to provide a reference.

\section{References}

Hertzel AV, et al. (2002). Increased lipolysis in transgenic animals overexpressing the epithelial fatty acid binding protein in adipose cells. J. Lipid Res. 43(12): 2105-2111

Liao, herong, Zhao, zong sheng, Li, Yan, Sun, Jie. (2004). Rick tournament. Rose crown chicken and chicken meat quality of different types of comparative study. China's poultry, 8 (1):176-178.

S. C. Nagaraia, S. E. Aggreyetc. (2000). Trait Association of a Genetic Marker in Egg-Laying Chikens. Heredity:91(2)150-156.

Seo D S, Yun J S, Kang W J. (2001). Association of insulin-like growth factor-1 gene polymorphism with serum IGF-1 concentration and body weight in Korean Native Ogol chicken Asian-Aust. J Anita Sci, 14 (7): 915-921.

Wang, Zhiyue, Fan, Ganglong, Yang, Haiming, Wang, Zhanggui, Sheng, Dongfeng, Liu, Guiqiong. (2004). New Yangzhou chicken IGF-1 gene polymorphism and early study on the relationship between growth rate. China's poultry, 26 (24):9-12 
Yang, Jianhua, Sun, Han, Lin, Shumao et al. (2003). Chicken insulin-like growth factor -1 genetic polymorphism and its relationship between body weight Journal of Animal Husbandry and Veterinary Medicine. 34 (6):525-529

Table 1. Different chicken IGF-1 by digestion Pst1 three genotype frequency and weight differences

\begin{tabular}{|c|c|c|c|c|c|}
\hline & genotype & frequency & birthweight & $\begin{array}{l}\text { Six week body } \\
\text { weight }\end{array}$ & $\begin{array}{l}\text { twelve week body } \\
\text { weight }\end{array}$ \\
\hline & “-/-"” & $20.97 \%$ & $38.77+0.378$ & $661.38+38.898$ & $1714.69+61.432$ \\
\hline \multirow[t]{3}{*}{$\mathrm{XA}$} & “+/_" & $32.26 \%$ & $38.05+0.473$ & $642.75+18.427$ & $1720.50+56.166$ \\
\hline & “+/+" & $46.77 \%$ & $38.66+0.489$ & $629.10+14.700$ & $1663.62+43.279$ \\
\hline & “-/-" & $30.00 \%$ & $47.11+0.851$ & $807.89+20.385^{\mathrm{a}}$ & $2382.94+66.718^{\mathrm{a}}$ \\
\hline \multirow[t]{3}{*}{$\mathrm{AX}$} & “+/_" & $30.00 \%$ & $47.72+0.976$ & $804.33+24.390^{\mathrm{a}}$ & $2221.50+74.914^{\mathrm{a}}$ \\
\hline & $"+/+"$ & $40.00 \%$ & $46.88+0.581$ & $723.88+14.777^{\mathrm{b}}$ & $1931.08+41.558^{\mathrm{b}}$ \\
\hline & “-/-_" & $22.00 \%$ & $36.73+1.251$ & $464.09+12.344^{\mathrm{a}}$ & $882.82+44.742^{\mathrm{a}}$ \\
\hline \multirow[t]{3}{*}{ MM } & “+/_" & $36.00 \%$ & $36.50+0.768$ & $422.56+18.978$ & $819.50+35.429$ \\
\hline & $"+/+"$ & $42.00 \%$ & $35.71+0.662$ & $407.86+11.102^{\mathrm{b}}$ & $767.38+27.154^{b}$ \\
\hline & “-/-" & $22.45 \%$ & $34.55+1.139$ & $504.55+14.542$ & $916.45+34.483$ \\
\hline \multirow[t]{4}{*}{$\mathrm{XX}$} & “+/_" & $38.78 \%$ & $33.79+0.538$ & $475.00+9.258$ & $841.84+24.718$ \\
\hline & “+/+" & $38.78 \%$ & $33.63+0.685$ & $473.11+11.324$ & $830.58+28.503$ \\
\hline & genotype & frequency & birthweight & $\begin{array}{l}\text { Six week body } \\
\text { weight }\end{array}$ & $\begin{array}{l}\text { nine week body } \\
\text { weight }\end{array}$ \\
\hline & “-/_" & $20.97 \%$ & $37.38+0.756$ & $1519.69+48.871$ & $2257.08+79.811$ \\
\hline \multirow[t]{2}{*}{$\mathrm{AA}$} & “+/_" & $32.26 \%$ & $38.05+0.634$ & $1508.10+53.832$ & $2210.75+86.695$ \\
\hline & “+/+" & $46.77 \%$ & $37.07+0.438$ & $1506.21+34.177$ & $2175.07+49.872$ \\
\hline
\end{tabular}

means significant difference at $\mathrm{P}<0.05$ in the same column with different superscripts 
Table 2. Different chicken IGF-1 by digestion Pst1 three different genotype frequency and gender differences in body

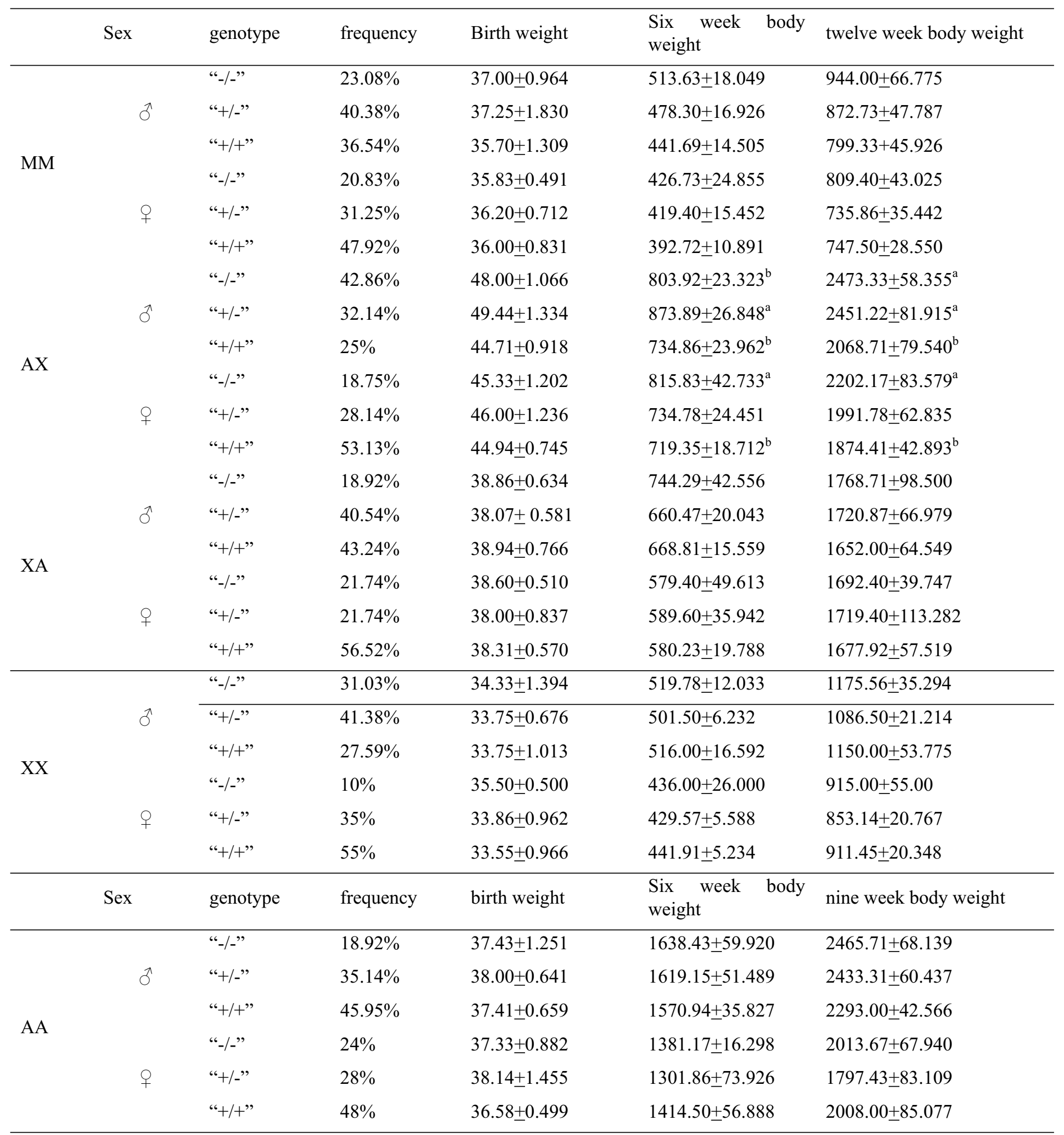

weight

means significant difference at $\mathrm{P}<0.05$ in the same column with different superscripts 


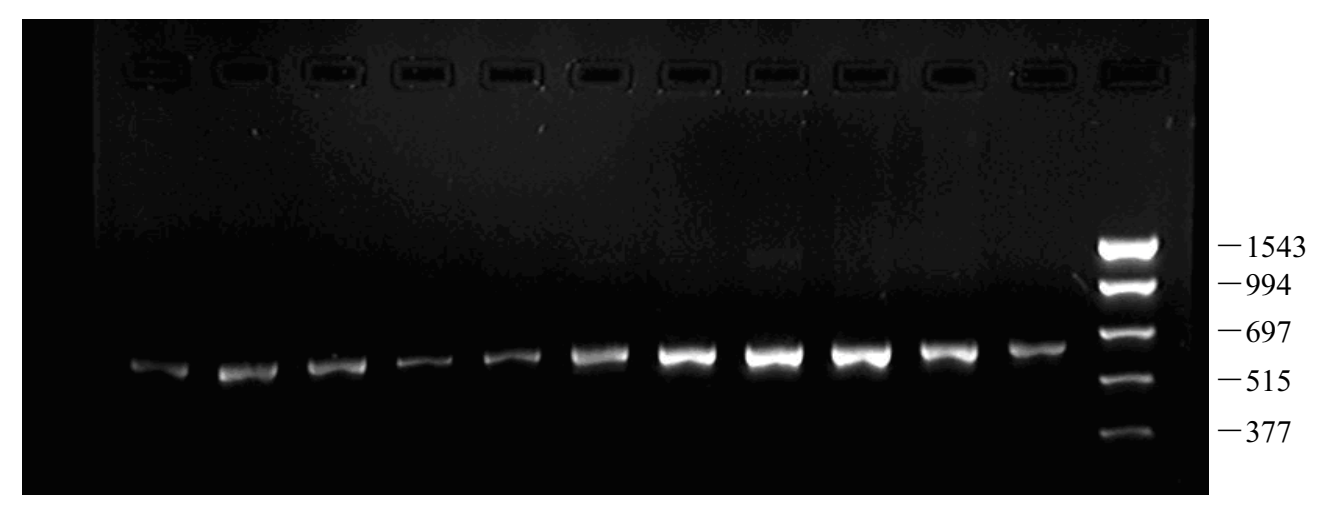

Figure 1. IGF-I gene regulatory region PCR products M: pBR322 DNA/Pst I

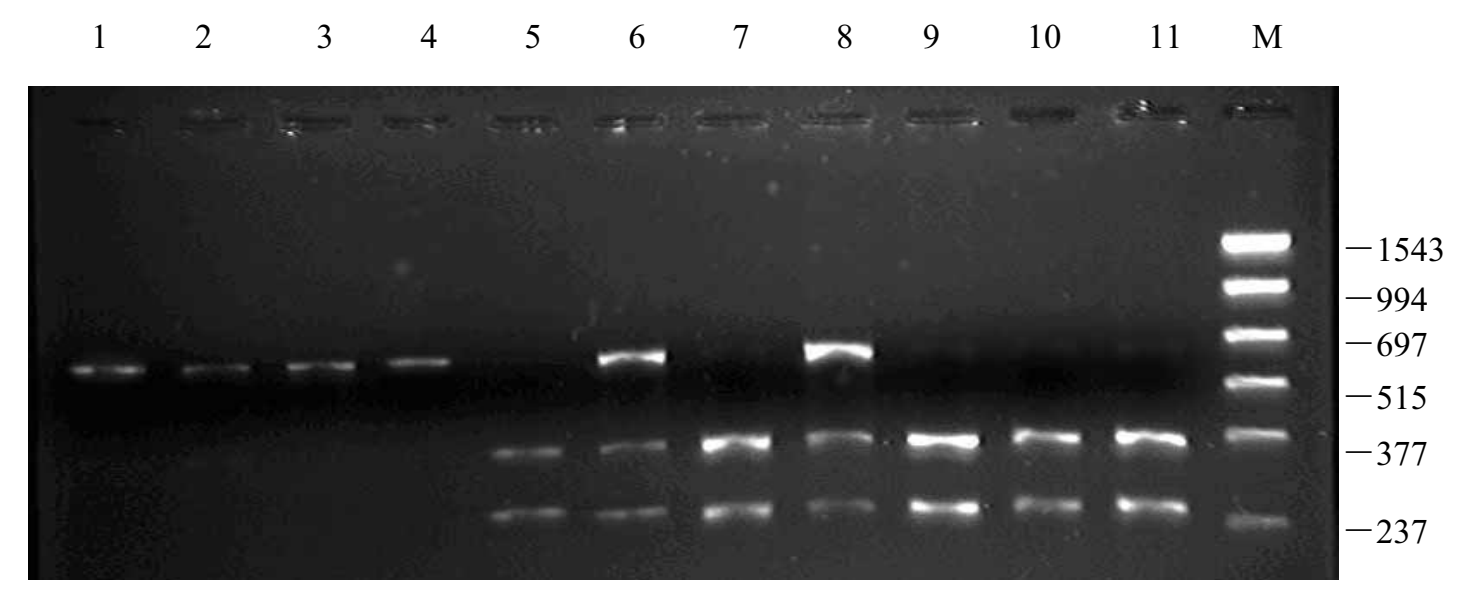

Figure 2. IGF-I gene PCR-RFLP results5,7,9,10,11:+/+;6,8:+/-;1,2,3,4:-/-; M:PCR DNA Markers 